\title{
The effect of various dietary fats, especially butter and some margarines, on blood cholesterol in rats
}

\author{
By J. P. FUNCH, E. NIELSEN AND H. DAM \\ Department of Biochemistry and Nutrition, Polytechnic Institute, Copenhagen
}

(Received 22 April 1959-Revised 4 August 1959)

The purpose of the experiments reported here was to study the effect of various dietary fats-whole butter, and fat mixtures made into whole margarines-on the blood-cholesterol levels in rats. Maize oil was subsequently given to some of the rats to discover whether it would cause a change in serum-cholesterol levels of rats previously fed on the margarine or butter diets.

\section{EXPERIMENTAL}

The study comprised three experiments, all with young male albino rats. Food and water were given $a d$ lib. The natures of the dietary fats are shown in Table 1 , the compositions of diets in Table 2. The rats were weighed and inspected weekly.

\section{Experiment I}

Rats, 6 weeks old, were distributed over eighteen groups, nine animals in each group, and three in each cage. The food consumption was estimated throughout the experiment. The dietary fats (cf. Table $\mathrm{r}$ ) were butter $\left(\mathrm{B}_{1}\right)$ and five margarines $\left(M_{1}, M_{2}, M_{3}, M_{4}\right.$ and $\left.M_{5}\right)$ made for the purpose. Each of these fats was given at dietary levels of 12,24 and $48 \%$ by weight (see Table 2 ). In margarine $M_{3}$, soya-bean oil was substituted for half of the rape-seed oil in margarine $\mathrm{M}_{2}$; in $\mathrm{M}_{4}$, the coconut oil of $\mathrm{M}_{5}$ was replaced by hydrogenated whale oil. At the end of the feeding period, which lasted 18 weeks, the rats were anaesthetized with ether, and heparinized blood was collected from the aortas for cholesterol determination by the method of Abell, Levy, Brodie \& Kendall (1952). Food cups were removed at 4 p.m. on the day before autopsy to avoid any possible variable increase in plasma cholesterol immediately after eating.

\section{Experiment 2}

In this experiment, in which the feeding period lasted 54 weeks, rats, 4 weeks old, were distributed over four groups with sixteen rats in each group, and two rats in each cage. The diets contained $24 \%$ margarine $\left(M_{6}, M_{7}, M_{8}\right)$ or butter $\left(B_{2}\right)$ (see Tables $I$ and 2).

After $36-45$ weeks on these diets, the cholesterol in the serum of the rats was determined: the tip of the tail was removed, and approximately $1 \mathrm{ml}$ blood was collected in a small centrifuge tube. After coagulation the serum was separated by centrifugation, and cholesterol was determined in duplicate portions of $0.1 \mathrm{ml}$, as 
described by Abell et al. (1952). At the end of the 54 weeks' feeding period half of the rats in each group were killed with chloroform to investigate the influence of the margarines and butter concerned on the macroscopic appearance of tissues and on the histological picture of heart, kidneys and liver. Paraffin sections were stained in the usual way with haematoxylin and eosin. Material from all the livers was also cut on a freezing microtome and stained for fat with Sudan black. Cholesterol was determined in the serum of the remaining rats, which were used for Expt 3 .

\section{Table I. Percentage composition and constitution of dietary fats used in Expts 1, 2 and 3}

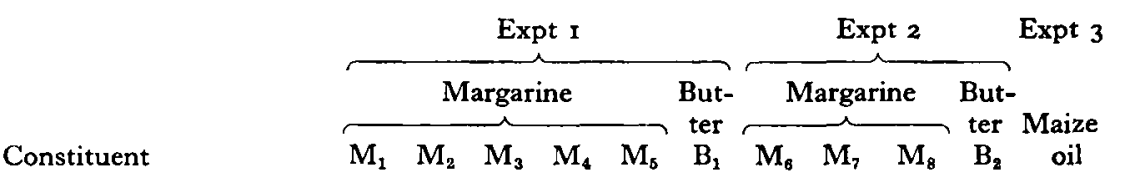

\begin{tabular}{|c|c|c|c|c|c|c|c|c|c|c|c|}
\hline Hydrogenated herring oil (m.p. $40-42^{\circ}$ ) & 10 & - & - & - & - & - & $17 \cdot 5$ & 一 & 一 & - & - \\
\hline Hydrogenated whale oil (m.p. $40-42^{\circ}$ ) & 15 & $19 \cdot 8$ & 19.8 & - & - & - & $12 \cdot 5$ & $19 \cdot 83$ & 一 & - & - \\
\hline Hydrogenated whale oil (m.p. $3^{8-40^{\circ}}$ ) & - & - & - & 一 & - & - & - & - & 17 & 一 & 一 \\
\hline Hydrogenated whale oil (m.p. $\left.30-32^{\circ}\right)$ & - & - & - & 95 & 60 & - & - & -4 & 44 & - & 一 \\
\hline Hydrogenated rape-seed oil (m.p. $40-42^{\circ}$ ) & - & $6 \cdot 6$ & $6 \cdot 6$ & - & - & - & 一 & Io & - & - & - \\
\hline Coconut oil & 45 & 45 & 45 & - & 35 & - & $46 \cdot 5$ & 45 & 30 & $一$ & - \\
\hline Palm oil & 20 & - & - & - & - & 一 & 20 & - & 一 & - & - \\
\hline Arachis oil & - & 一 & - & 5 & 5 & - & - & - & 5 & - & - \\
\hline Rape-seed oil & - & $28 \cdot 6$ & $14 \cdot 3$ & - & - & - & - & $25 \cdot 03$ & - & - & - \\
\hline Soya-bean oil & $6 \cdot 5$ & - & $14 \cdot 3$ & - & 一 & - & - & - & 4 & - & - \\
\hline Sesame oil & $2 \cdot 5$ & 一 & - & - & - & - & $2 \cdot 5$ & - & - & - & 一 \\
\hline Vitamin oil* & $1 \cdot 0$ & 一 & - & - & - & - & $1 \cdot 0$ & 0.14 & 0.025 & - & - \\
\hline Vitamin A (i.u./g dietary fat) & 14 & 27.8 & $27 \cdot 8$ & 20 & 20 & $3 I \cdot 6$ & 14 & $26 \cdot 5$ & 20 & $t$ & - \\
\hline Carotene (i.u./g dietary fat) & 6 & $3 \cdot 7$ & 3.7 & $\mathbf{o}$ & $\circ$ & $8 \cdot 1$ & 6 & 3 & o & $t$ & - \\
\hline Vitamin D (i.u./g dietary fat) & 0.5 & $1 \cdot 5$ & $1 \cdot 5$ & $2 \cdot 5$ & $2 \cdot 5$ & $t$ & 0.5 & $1 \cdot 5$ & $2 \cdot 5$ & $t$ & $\longrightarrow$ \\
\hline Polyene fatty acids $\ddagger(\mathrm{g} / 100 \mathrm{~g}$ fat $)$ : & & & & & & & & & & & \\
\hline Dienoic & $7 \cdot 1$ & $5^{\cdot 1}$ & $8 \cdot 3$ & $1 \cdot 5$ & $1 \cdot 7$ & $1 \cdot 7$ & t & t & 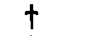 & $\dagger$ & 42 \\
\hline Trienoic & 0.4 & $2 \cdot 3$ & $2 \cdot 0$ & $\mathbf{o}$ & $\circ$ & 0.8 & $t$ & t & $t$ & $t$ & 0.5 \\
\hline Tetraenoic & $\mathbf{o}$ & 0.1 & 0.2 & ० & $\circ$ & 0.2 & $\dagger$ & $\dagger$ & $t$ & $t$ & 0 \\
\hline Pentaenoic & 0 & 0.1 & 0.1 & $\circ$ & 0 & 0.1 & + & $t$ & $t$ & $t$ & 0 \\
\hline Hexaenoic & 0.2 & 0.1 & 0.4 & 0.1 & 0.1 & 0.1 & $t$ & $t$ & $t$ & $t$ & 0 \\
\hline
\end{tabular}

* Vitamin $A$, carotene and vitamins $D_{2}$ and $D_{3}$ from natural sources or of synthetic origin dissolved in soya-bean oil (margarines $M_{1}$ and $M_{8}$ ), rape-seed oil (margarine $M_{7}$ ) or arachis oil (margarine $M_{8}$ ).

+ Not estimated.

I Estimated by the alkali-isomerization procedure described by Hammond \& Lundberg (1953). Values obtained by this method for hydrogenated fat may be used for guidance and comparison, but the validity of the absolute values remains to be established.

\section{Experiment 3}

This experiment was a continuation of Expt 2 . All the rats were caged individually and were fed on a diet containing $21.7 \%$ maize oil, which provided $40 \%$ of the total calories (see Table 2). The amounts of polyene fatty acids in the maize oil are shown in Table I. Determinations of serum cholesterol, by the method described for Expt 2, were made shortly before the animals were placed on the maize-oil diet and again I month and 4 months afterwards. The food consumption was estimated throughout the experiment. 
Table 2. Percentage composition of diets

\begin{tabular}{|c|c|c|c|c|c|c|c|}
\hline $\begin{array}{c}\text { Expt } \\
\text { no. }\end{array}$ & Group no. & Dietary fat* & $\begin{array}{l}\text { Crude } \\
\text { casein } \dagger\end{array}$ & Sucrose & $\begin{array}{c}\text { Salt } \\
\text { mixturef }\end{array}$ & $\begin{array}{l}\text { Vitamin } \\
\text { mixture§ }\end{array}$ & $\begin{array}{l}\text { Choline } \\
\text { chloride }\end{array}$ \\
\hline I & $113-x 18 \|$ & $\begin{array}{l}12 \% \text { margarine } M_{1}-M_{5} \\
\text { or butter } B_{1}\end{array}$ & 20 & 63 & 4 & 0.5 & 0.5 \\
\hline $\mathbf{I}$ & $\begin{array}{l}119-124 \| \\
125-130 \|\end{array}$ & $\begin{array}{l}24 \% \text { margarine } M_{1}-M_{6} \\
\text { or butter } B_{1} \\
48 \% \text { margarine } M_{1}-M_{6} \\
\text { or butter } B_{1}\end{array}$ & 20 & $\begin{array}{l}51 \\
27\end{array}$ & 4 & $\begin{array}{l}0.5 \\
0.5\end{array}$ & $\begin{array}{l}0.5 \\
0.5\end{array}$ \\
\hline 2 & $\begin{array}{l}131 \\
132 \\
133 \\
134\end{array}$ & $\begin{array}{l}24 \% \text { margarine } M_{6} \\
24 \% \text { margarine } M_{7} \\
24 \% \text { margarine } M_{8} \\
24 \% \text { butter } B_{2}\end{array}$ & $\begin{array}{l}20 \\
20 \\
20 \\
20\end{array}$ & $\begin{array}{l}50 \cdot 96 \\
50 \cdot 94 \\
51 \cdot 0 \\
50 \cdot 0\end{array}$ & $\begin{array}{l}4.045 \\
4.069 \\
4.09 \\
4.29\end{array}$ & $\begin{array}{l}0.5 \\
0.5 \\
0.5 \\
0.5\end{array}$ & $\begin{array}{l}0.5 \\
0.5 \\
0.5 \\
0.5\end{array}$ \\
\hline 3 & $15 \mathrm{I}-154$ & $21 \cdot 7 \%$ maize oil & 20 & $53 \cdot 3$ & 40 & 0.5 & 0.5 \\
\hline
\end{tabular}

* See Table I.

† Obtained from Dansk Mejeri Industri and Export Kompagni Ltd, Stege, Denmark.

The composition of the salt mixture was: $\left[\mathrm{CH}_{3} \mathrm{CH}(\mathrm{OH}) \mathrm{COO}\right]_{2} \mathrm{Ca} .5 \mathrm{H}_{2} \mathrm{O}, 3900 \mathrm{~g} ; \mathrm{Fe} \mathrm{C}_{6} \mathrm{H}_{5} \mathrm{O}_{7} \cdot{ }_{3} \mathrm{H}_{2} \mathrm{O}$, $355 \mathrm{~g} ; \mathrm{K}_{2} \mathrm{HPO}_{4}, 2862 \mathrm{~g} ; \mathrm{CaH}_{4}\left(\mathrm{PO}_{4}\right)_{2} \cdot \mathrm{H}_{2} \mathrm{O}, \mathrm{I}_{20} \mathrm{~g} ; \mathrm{NaH}_{2} \mathrm{PO}_{4} \cdot \mathrm{H}_{2} \mathrm{O}, \mathrm{IO}_{4} \mathrm{I} \mathrm{g} ; \mathrm{MgSO}_{4}, 798 \mathrm{~g} ; \mathrm{NaCl}, 519 \mathrm{~g}$; $\mathrm{CuSO}_{4} \cdot 5 \mathrm{H}_{2} \mathrm{O}, \mathrm{I} 5 \mathrm{~g} ; \mathrm{MnSO}_{4} \cdot 4 \mathrm{H}_{2} \mathrm{O}, 60 \mathrm{~g} ; \mathrm{KI}, \mathrm{I} \cdot 5 \mathrm{~g}$; total 1 I I 7 I. $5 \mathrm{~g}$.

$\S 500 \mathrm{~g}$ of the vitamin mixture consisted of: biotin, $50 \mathrm{mg}$; folic acid, $50 \mathrm{mg} ; p$-aminobenzoic acid, $35 \mathrm{~g}$; thiamine hydrochloride, $5 \mathrm{~g}$; riboflavin, $5 \mathrm{~g}$; pyridoxine hydrochloride, $5 \mathrm{~g}$; calcium pantothenate, $5 \mathrm{~g}$; nicotinic acid, $8 \mathrm{~g}$; inositol, $15 \mathrm{~g}$; ascorbic acid, $5 \mathrm{~g}$; DL- $\alpha$-tocopheryl acetate (Ephynal, Roche Products Ltd), $5 \mathrm{~g}$; dicalcium salt of 2-methyl-1, 4-naphthohydroquinone diphosphoric acid (Synkavit, Roche Products Ltd), I g; and sucrose to $500 \mathrm{~g}$.

II The fats given to each group are listed in Table 3 .

The amount of sodium chloride present in the different fat compounds was allowed for, so that the sodium-chloride content of all diets was the same.

\section{RESULTS}

\section{Experiment I}

Plasma cholesterol was determined at the end of the 18 weeks' feeding period. The mean cholesterol values for each group as well as the calorie intake during the feeding period, and initial and final weights of the rats are listed in Table 3.

At all three dietary levels (12, 24 and $48 \%$ ), margarines $M_{4}$ and $M_{5}$ gave significantly lower plasma-cholesterol values than margarine $\mathrm{M}_{1}$ and butter $\mathrm{B}_{1}(P<0.0 \mathrm{r})$. At the $24 \%$ dietary level, $M_{4}$ and $M_{5}$ caused significantly lower plasma-cholesterol values than $\mathrm{M}_{2}$ and $\mathrm{M}_{3}(P<0.0 \mathrm{r})$; the effect at the $\mathrm{I} 2$ and $48 \%$ dietary levels, however, was only on the borderline of significance ( $P$ about 0.05$)$.

Butter $B_{1}$, and margarines $M_{1}, M_{2}$ and $M_{3}$ did not differ significantly in their effect on plasma cholesterol at $\mathrm{I} 2$ and $24 \%$ dietary levels. At the $48 \%$ dietary level, butter increased plasma cholesterol significantly, compared with $\mathrm{M}_{1}(P=0.05)$ as well as with $\mathrm{M}_{2}$ and $\mathrm{M}_{3}(P<0.0 \mathrm{I})$.

It will be seen from Table 3 that the differences in effect of the diet on plasma cholesterol cannot be accounted for by differences in calorie intake or growth, since there was no consistent relationship between plasma-cholesterol values on the one hand and calorie intake or final weight on the other. 


\section{Experiment 2}

The mean serum-cholesterol values and weight gains for each group are listed in Table 4.

After an experimental period of $36-45$ weeks the rats fed on margarine $M_{7}$ (group I32) or $M_{8}$ (group I33) had significantly lower serum-cholesterol levels than those fed on butter $\mathrm{B}_{2}$ (group 134) $(P<0.01)$, whereas the serum-cholesterol values of the rats

Table 3. Expt 1. Mean values for plasma cholesterol of rats after 18 weeks on the experimental diets, calorie intake during this period, and mean weights at the end of the experimental period*

(Nine observations for each value)

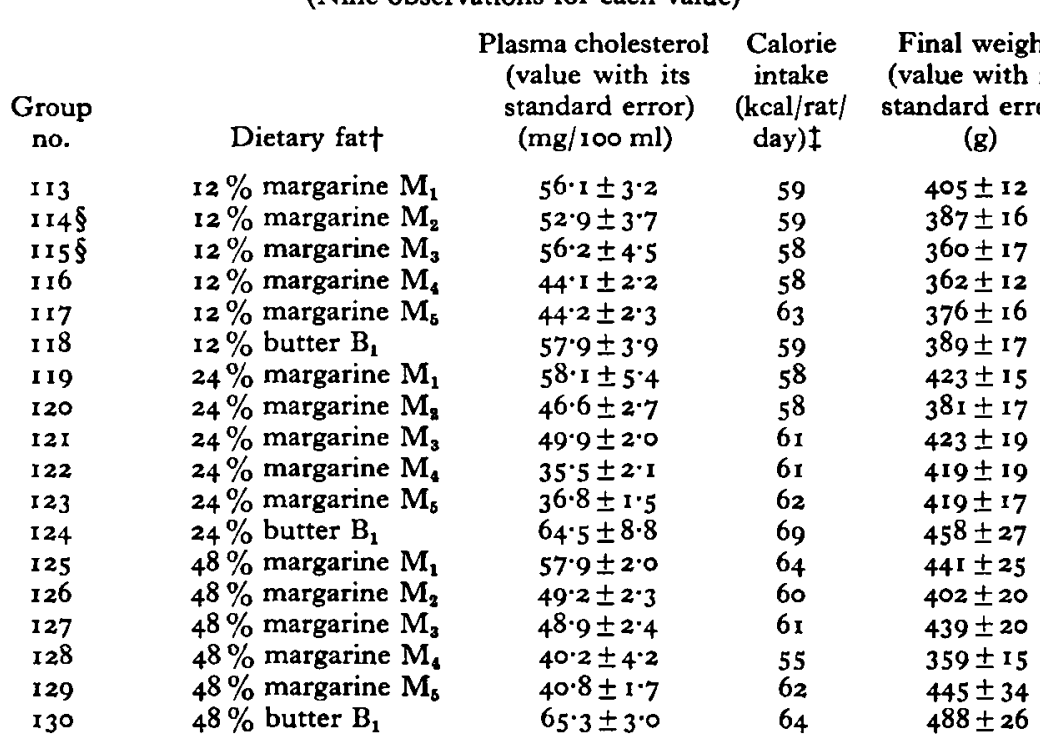

- Mean initial weight of rats in each group, $112 \mathrm{~g}$.

+ See Table r.

I Calculated on the assumption that protein and carbohydrate yield $4 \mathrm{kcal} / \mathrm{g}$ and fat $9 \mathrm{kcal} / \mathrm{g}$.

§ In group 114 eight observations and in group 115 seven observations, since three animals got necrotic and diphtheritic enteritis and were killed before the end of the experiment.

Table 4. Expt 2. Mean values with their standard errors for serum cholesterol, and mean weight gains of rats, during the period 36-45 weeks and during the whole 54 weeks on the experimental diet*

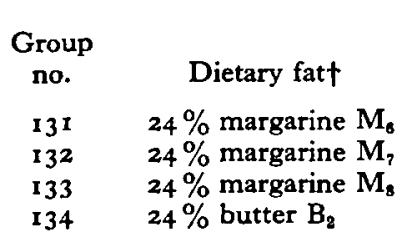

$\begin{array}{cr}\text { After } 36-45 \text { weeks } & \text { After } 54 \text { weeks } \\ 92 \cdot 7 \pm 5.5(15) & 102 \cdot 6 \pm 9 \cdot 9(7) \\ 79.6 \pm 4.2(14) & 81 \cdot 1 \pm 7.9(7) \\ 80 \cdot 2 \pm 4.1(14) & 77 \cdot 0 \pm 4 \cdot 4(6) \\ 104.1 \pm 6.3(15) & 93.3 \pm 8 \cdot 1(8)\end{array}$

\begin{tabular}{|c|c|}
\hline \multicolumn{2}{|c|}{ Weight gain $\downarrow$ (g) } \\
\hline $36-45$ weeks & 54 weeks \\
\hline $\begin{array}{r}8(15) \\
\text { II (14) } \\
\text { I } 4 \text { (I4) } \\
\text { II (15) }\end{array}$ & $\begin{array}{l}53 \text { I (7) } \\
516(7) \\
490(6) \\
507(8)\end{array}$ \\
\hline
\end{tabular}

- Initial weight of rats, 45-6o g.

+ See Table I.

$\ddagger$ Number of observations in parentheses. 
fed on $M_{6}$ (group I 3 ) were not significantly different from those of the rats in the other groups $(P>0.05)$.

At the end of the experiment, which lasted 54 weeks, the autopsies performed on half of the rats of each group and the histological examination of hearts and kidneys of

Table 5. Expt 3. Individual values for serum cholesterol, initially, after I month and after 4 months, and amount of food eaten and change in weight during these periods of rats on a diet containing $21.7 \%$ maize oil

\begin{tabular}{|c|c|c|c|c|c|c|c|c|c|c|}
\hline \multirow[b]{2}{*}{$\begin{array}{c}\text { Group } \\
\text { no. }\end{array}$} & \multirow[b]{2}{*}{$\begin{array}{l}\text { Rat } \\
\text { no. }\end{array}$} & \multirow{2}{*}{$\begin{array}{l}\text { Dietary fat* } \\
\text { for } 54 \text { weeks } \\
\text { before the } \\
\text { experiment }\end{array}$} & \multicolumn{3}{|c|}{ Serum cholesterol (mg/100 ml) } & \multicolumn{2}{|c|}{ Food eaten/day (g) } & \multicolumn{3}{|c|}{ Weight change (g) } \\
\hline & & & $\begin{array}{l}\text { At the } \\
\text { beginning }\end{array}$ & $\begin{array}{c}\text { After } \\
\text { I month }\end{array}$ & $\begin{array}{c}\text { After } \\
4 \text { months }\end{array}$ & $\begin{array}{l}\text { During } \\
\text { I month }\end{array}$ & $\begin{array}{l}\text { During } \\
4 \text { months }\end{array}$ & $\begin{array}{l}\text { weight } \\
\text { (g) }\end{array}$ & During & $\begin{array}{l}\text { During } \\
4 \text { months }\end{array}$ \\
\hline \multirow[t]{5}{*}{151} & $\mathbf{I}$ & \multirow[t]{5}{*}{$24 \%$ margarine $\mathbf{M}_{6}$} & 105 & I I 3 & 93 & $16 \cdot 9$ & $17 \cdot 2$ & 660 & +12 & +31 \\
\hline & $\begin{array}{l}5 \\
8\end{array}$ & & $\begin{array}{r}78 \\
122\end{array}$ & $\begin{array}{r}75 \\
123\end{array}$ & $\begin{array}{r}71 \\
108\end{array}$ & $14 \cdot 6$ & $14 \cdot 2$ & 482 & $\begin{array}{l}+13 \\
+21\end{array}$ & $\begin{array}{r}+9 \\
-95\end{array}$ \\
\hline & 12 & & 124 & 137 & 128 & $\begin{array}{l}14 \cdot 1 \\
16 \cdot 2\end{array}$ & 15.4 & $\begin{array}{l}491 \\
560\end{array}$ & +21 & $\begin{aligned}-45 \\
-10\end{aligned}$ \\
\hline & $\begin{array}{l}16 \\
20\end{array}$ & & $\begin{array}{l}92 \\
63\end{array}$ & $\begin{array}{l}92 \\
88\end{array}$ & $\begin{array}{r}113 \\
60\end{array}$ & $\begin{array}{l}15 \cdot 7 \\
17 \cdot 2\end{array}$ & $\begin{array}{l}16 \cdot 2 \\
16 \cdot 8\end{array}$ & $\begin{array}{l}55^{8} \\
680\end{array}$ & $\begin{array}{r}+3 \\
+15\end{array}$ & $\begin{array}{l}-17 \\
-45\end{array}$ \\
\hline & Mean & & $97 \cdot 3$ & $104 \div 7$ & $95 \cdot 5$ & $15 \cdot 8$ & $15 \cdot 4$ & $571 \cdot 8$ & $+14 \cdot 2$ & $-12 \cdot 8$ \\
\hline \multirow[t]{7}{*}{ r52 } & & \multirow[t]{7}{*}{$24 \%$ margarine $\mathrm{M}_{7}$} & 72 & 54 & 50 & $12 \cdot 8$ & $12 \cdot 5$ & 531 & -18 & -127 \\
\hline & 21 & & 55 & 71 & 6I & $15 \cdot 9$ & $15 \cdot 5$ & 535 & +13 & -6 \\
\hline & $\begin{array}{l}22 \\
23\end{array}$ & & $\begin{array}{r}04 \\
\text { r } 19\end{array}$ & $\begin{array}{r}80 \\
128\end{array}$ & $\begin{array}{r}49 \\
135\end{array}$ & $\begin{array}{l}15 \cdot 3 \\
13 \cdot 7\end{array}$ & $\begin{array}{l}16.0 \\
14.8\end{array}$ & $\begin{array}{l}604 \\
610\end{array}$ & $\begin{array}{l}-13 \\
-48\end{array}$ & $\begin{array}{r}-24 \\
-132\end{array}$ \\
\hline & 24 & & 84 & IOI & 99 & $14 \cdot 8$ & 14.8 & 573 & +8 & -85 \\
\hline & 25 & & 81 & 105 & 134 & $16 \cdot 7$ & $16 \cdot 6$ & 609 & +5 & -59 \\
\hline & 26 & & 94 & 105 & 98 & $16 \cdot 6$ & $14^{\circ} 9$ & 488 & +9 & -34 \\
\hline & Mean & & $8 x \cdot 3$ & $92 \cdot 0$ & 89.4 & $15^{\cdot 1}$ & I5.0 & $564: 3$ & $-6 \cdot 3$ & $-66 \cdot 7$ \\
\hline \multirow[t]{6}{*}{153} & 28 & \multirow[t]{6}{*}{$24 \%$ margarine $M_{8}$} & 64 & 105 & 113 & $15 \cdot 1$ & $14 \cdot 6$ & 446 & +29 & +46 \\
\hline & $\begin{array}{l}29 \\
34\end{array}$ & & $\begin{array}{l}84 \\
86\end{array}$ & $\begin{array}{l}108 \\
130\end{array}$ & $\begin{array}{r}134 \\
60\end{array}$ & $\begin{array}{l}17 \cdot 2 \\
18 \cdot 5\end{array}$ & $\begin{array}{l}15.6 \\
18.5\end{array}$ & $\begin{array}{l}521 \\
638\end{array}$ & $\begin{array}{l}+39 \\
-38\end{array}$ & $\begin{array}{l}+39 \\
-99\end{array}$ \\
\hline & 53 & & 82 & 119 & 142 & $18 \cdot 7$ & $16 \cdot 1$ & $52 x$ & +58 & +28 \\
\hline & $5^{8}$ & & 62 & 87 & 72 & $12 \cdot 1$ & $15 \cdot 2$ & 620 & -47 & -81 \\
\hline & 70 & & 83 & 78 & 85 & $17 \cdot 0$ & $16 \cdot 3$ & 509 & $+3^{8}$ & $+5 I$ \\
\hline & Mean & & $76 \cdot 8$ & 104.5 & 101.0 & 16.4 & $16 \cdot 1$ & $542 \cdot 5$ & +13.2 & $-2 \cdot 7$ \\
\hline \multirow[t]{8}{*}{154} & 43 & \multirow[t]{7}{*}{$24 \%$ butter $B_{2}$} & 85 & 99 & 95 & 15.5 & $15 \cdot 2$ & 491 & +13 & +7 \\
\hline & $\begin{array}{l}45 \\
46\end{array}$ & & $\begin{array}{r}79 \\
145\end{array}$ & $\begin{array}{r}94 \\
148\end{array}$ & $\begin{array}{l}75 \\
95\end{array}$ & $\begin{array}{l}14.2 \\
13.8\end{array}$ & $\begin{array}{l}13 \cdot 1 \\
16 \cdot 8\end{array}$ & $\begin{array}{l}45 I \\
629\end{array}$ & $\begin{array}{l}+12 \\
-41\end{array}$ & $\begin{array}{l}-51 \\
-79\end{array}$ \\
\hline & 48 & & 92 & 124 & 119 & 13.2 & $13 \cdot 2$ & 474 & +10 & -20 \\
\hline & 50 & & 83 & 99 & 98 & $12 \cdot 4$ & $15 \cdot 6$ & 521 & -6 & +9 \\
\hline & 51 & & 90 & 118 & 112 & 12.9 & 147 & 593 & -23 & -45 \\
\hline & 67 & & IOI & 124 & 103 & $17 \cdot 3$ & $16 \cdot 6$ & 754 & +24 & -54 \\
\hline & 68 & & 71 & 81 & 86 & $17 \cdot 5$ & $16 \cdot 5$ & 549 & +16 & +1 \\
\hline & \multicolumn{2}{|c|}{ Mean } & $93 \cdot 3$ & 110.9 & $97 \cdot 9$ & $14^{\cdot 6}$ & $15 \cdot 2$ & $557 \cdot 8$ & +0.6 & $-29 \cdot 0$ \\
\hline
\end{tabular}

these rats did not reveal any significant abnormalities. However, the rats fed on margarine showed a moderate accumulation, and the rats fed on butter showed a marked accumulation, of stainable fat in the livers. The fat was located primarily in cells in the region of the portal triad. The nuclei of the fat-laden cells showed no pathological changes.

Serum-cholesterol determinations were made on samples from those rats selected 
for Expt 3. By this time the serum-cholesterol values showed the same trend as was seen after $36-45$ weeks.

From Table 4 it will be seen that there seemed to be no consistent relationship between the values for serum cholesterol and the weight gains of the rats.

\section{Experiment 3}

It can be seen from Table 5 that feeding on a maize-oil diet for I month, after 54 weeks on a margarine or butter diet, increased the serum-cholesterol values slightly in the rats previously fed on $M_{6}, M_{7}$ or $B_{2}$ (groups $I_{5} I, I_{52}$ and ${ }_{54}$ ) and markedly in the rats that initially had low serum-cholesterol values after being fed on $\mathbf{M}_{8}$ (group 153). After subsequent feeding for 3 months on the maize-oil diet the increased cholesterol levels were maintained in the rats previously fed on $M_{8}$, whereas the cholesterol levels of the rats in groups 151,152 and 154 had returned to nearly the initial levels. The decrease in weight which occurred in some rats of these groups may have been responsible for the return of cholesterol values to initial levels.

\section{DISCUSSION}

In these experiments with rats fed on diets containing margarine or butter, the butter diets consistently caused a significant increase in plasma or serum cholesterol, compared with the margarines $M_{4}, M_{5}$ or $M_{8}$.

A change from $M_{8}$ to maize oil significantly increased the serum-cholesterol values, but a similar change from margarines $M_{6}$ and $M_{7}$ or butter had no such effect. The distinguishing feature of $M_{4}, M_{5}$ and $M_{8}$ is a high content of hydrogenated whale oil $(95,60$ and $6 \mathrm{I} \%$, respectively, cf. Table I) and a concomitant low content of polyene fatty acids compared with that of the other margarines.

The increase in serum cholesterol observed in rats fed on diets containing butter is in agreement with the experience in man of Ahrens, Hirsch, Insull, Tsaltas, Blomstrand \& Peterson (1957), Beveridge, Connell \& Mayer (1956, 1957), Beveridge, Connell, Mayer, Firstbrook \& DeWolfe (1955), Malmros \& Wigand (I957) and others, who have shown that ingestion of butter (a highly saturated fat with only small amounts of poly-unsaturated fatty acids) elevates the blood-cholesterol level in man. These workers also showed that a highly unsaturated oil containing large amounts of poly-unsaturated fatty acids, such as maize oil, lowers the cholesterol levels in human blood, a finding in contrast with the results of our own experiments on rats.

The finding of a low serum-cholesterol level in rats fed on a diet containing fat saturated by hydrogenation $\left(M_{4}, M_{5}\right.$ and $M_{8}$, cf. Table $\left.I\right)$ agrees with the results of Swell, Flick, Field \& Treadwell (1955). These investigators found that in rats fed on soya-bean oil hydrogenated to varying degrees the most saturated fat produced the lowest blood-cholesterol level. Our finding, that substitution of a dietary fat containing high amounts of linoleic acid (maize oil) for a fat containing small amounts of linoleic acid (margarine $\mathrm{M}_{8}$ ) significantly increased the serum-cholesterol values in rats, confirms the results of Klein (1958). In his experiment the rats showed an increase in plasma cholesterol when the linoleic-acid content of the diet was increased. This 
finding is contrary to what might be expected from results in man, in whom the ingestion of highly unsaturated oils generally results in low serum-cholesterol levels. However, the composition of the basal diet seems to exert a decisive influence on the way in which dietary fat changes blood-cholesterol levels in rats. Thus, using diets supplemented with cholesterol and bile salts, Aftergood, Deuel \& Alfin-Slater (I957) found lower plasma-cholesterol concentrations in rats fed on highly unsaturated fat (cottonseed oil) than in those fed on more saturated fat (lard). Similar results were obtained by Hegsted, Andrus, Gotsis \& Portman (1957) who found that maize oil lowered the serum-cholesterol content in rats fed on a diet containing cholesterol and cholic acid and producing hypercholesterolæmia. Using a hypercholesterolæmic diet containing $10 \%$ hydrogenated coconut oil and $\mathrm{x} \%$ cholesterol, Hauge \& Nicolaysen $(1959 a, b)$ also found that the effects of the oils and fatty acids tested on hypercholesterolæmic rats were similar to their reported effects on serum-cholesterol levels in human beings.

In our experiments, the difference in effect on blood-cholesterol level obtained with butter and the margarines containing large amounts of hydrogenated whale oil $\left(\mathrm{M}_{4}, \mathrm{M}_{5}\right.$, $\mathrm{M}_{8}$ ) may have been due, at least in part, to a difference in chain length of the fatty acids. These margarines and the butter contain approximately the same amounts of polyene fatty acids. However, about $25 \%$ by weight of the fatty acids of butter have chain lengths of from $\mathrm{C}_{4}$ to $\mathrm{C}_{14}$ and negligible amounts of acids with chain lengths greater than $\mathrm{C}_{18}$, whereas $25-30 \%$ of the fatty acids of whale oil have chain lengths of from $\mathrm{C}_{20}$ to $\mathrm{C}_{22}$ (Hilditch, 1956).

\section{SUMMAR Y}

I. The purpose of the three experiments reported here was to study the influence of dietary fat on the blood-cholesterol levels in male rats fed ad lib. on the experimental diets from the age of 4 or 6 weeks.

2. In Expt I cholesterol was determined in the plasma of 159 rats distributed over eighteen groups fed for 18 weeks on diets containing 12,24 and $48 \%$ by weight of butter or one of five margarines.

3. In Expt 2 cholesterol was determined in the serum of fifty-eight rats distributed over four groups fed for $36-45$ weeks on diets with $24 \%$ of butter or of one of three margarines. After 54 weeks on these diets half of the rats were killed for histological examination and cholesterol was again determined in the serum of the remaining rats which were used for Expt 3. They were transferred to a diet containing $21 \cdot 7 \%$ maize oil instead of butter or margarine. Serum-cholesterol levels were again determined after I month and after 4 months on the maize-oil diet.

4. The butter diets consistently caused significantly higher blood-cholesterol levels than did the diets with margarines containing large amounts of hydrogenated whale oil. A change from these margarines to maize oil resulted in raised serum cholesterol, but a similar change from the other margarines or butter had no such effect.

5. The difference in chain length of the fatty acids present in butter and in those 
margarines containing large amounts of hydrogenated whale oil may have been partly responsible for the difference in effect of the two kinds of fat on plasma- or serumcholesterol levels.

\section{REFERENCES}

Abell, L. L., Levy, B. B., Brodie, B. B. \& Kendall, F. E. (1952). F. biol. Chem. I95, 357.

Aftergood, L., Deuel, H. J. Jr. \& Alfin-Slater, R. B. (1957). Э. Nutr. 62, 129.

Ahrens, E. H. Jr., Hirsch, J., Insull, W. Jr., Tsaltas, T. T., Blomstrand, R. \& Peterson, M. L. (1957). Lancet, 272, 943.

Beveridge, J. M. R., Connell, W. F. \& Mayer, G. A. (1956). Canad. F. Biochem. Physiol. 34, 441.

Beveridge, J. M. R., Connell, W. F. \& Mayer, G. A. (1957). Canad. F. Biochem. Physiol. $35,257$.

Beveridge, J. M. R., Connell, W. F., Mayer, G. A., Firstbrook, J. B. \& DeWolfe, M. S. (1955). F. Nutr. 56. 311 .

Hammond, E. G. \& Lundberg, W. O. (1953). F. Amer. Oil Chem. Soc. 30, 433.

Hauge, J. G. \& Nicolaysen, R. (I959a). Acta physiol. scand. 45, 19.

Hauge, J. G. \& Nicolaysen, R. (1959b). Acta physiol. scand. 45, 26.

Hegsted, D. M., Andrus, S. B., Gotsis, A. \& Portman, O. W. (1957). F. Nutr. 63, 273.

Hilditch, T. P. (1956). The Chemical Constitution of Natural Fats, 3rd ed. London: Chapman and Hall Ltd.

Klein, P. D. (1958). Arch. Biochem. Biophys. 76, 56.

Malmros, H. \& Wigand, G. (1957). Lancet, 273, 1.

Swell, L., Flick, D. F., Field, H. Jr. \& Treadwell, C. R. (1955). Amer. F. Physiol. I80, 124. 